\title{
Impact of Rainfall on Agricultural Growth in Thailand: Evidence in Farming and Fishing Activities
}

\author{
Siriklao Sangkhaphan ${ }^{1} \quad$ Yang Shu $^{2 *}$ \\ 1.School of Economics, Huazhong University of Science and Technology, 1037 Luoyu Road, Wuhan 430074, \\ P.R. China \\ 2.School of Economics and Trade, Hunan University, Lushan S. RD, Changsha, Hunan, China
}

\begin{abstract}
Rainfall is related to economic growth. This is especially true for the agricultural sector which is a key food source. Rainfall has beneficial impacts in both arid and poor regions. Thailand, as an upper middle-income country according to the World Bank, has a tropical climate although rainfall varies between each region. Precipitation in the northern and northeastern regions is low while the southern region, as a narrow strip of land running northsouth bordering the Andaman Sea to the West and the Gulf of Thailand to the East, has the highest rainfall. Agricultural product characteristics differ between regions. In arid areas, agrarian products are largely from farming while fisheries predominate in the southern region. The effect of rainfall on GDP growth was explored on a region-by-region basis using panel data from 2004 to 2015 at provincial level. The FGLS (Feasible Generalized Least Square) estimator was used in the regression models. Results showed that in northeastern and northern regions, rainfall stimulated economic growth in all dimensions of the agricultural sector and agricultural subsectors. The economic impact of rainfall played a major role in the fishing subsectors compared to the farming subsector. Overall, results identified the regions and agricultural subsectors that were economically profitable as a result of increased rainfall.
\end{abstract}

Keywords: Rainfall, Economic growth, Agricultural subsector, FGLS estimator, Panel data

DOI: $10.7176 / \mathrm{JESD} / 10-16-19$

Publication date: August $31^{\text {st }} 2019$

\section{Introduction}

It is widely accepted that variations in global climate change will have crucial impacts on agriculture and the environment including water resources, fisheries, forests, wildlife and ecosystems (Murad, Islam Molla, Bin Mokhtar, \& Raquib, 2010). There is now agreement strong consensus among scientists that anthropogenic changes are already detectable due to the burning of fossil fuels and release of carbon dioxide and other greenhouse gases into the atmosphere, resulting in global warming and changes in precipitation patterns (IPCC, 2007). Many impacts are expected from global climate change and one of the largest is forecast to be in agriculture (Cline, 2007; Nordhaus, 1991) because of the size and sensitivity of the sector (Mendelsohn, 2008).

The climatic variables of temperature and rainfall are often represented in economic growth models within the field of climate change, mostly focused on temperature. The available literatures suggests that increase in temperature has a negative impact on economic growth (Akram, 2012; Lanzafame, 2014; Sequeira, Santos, \& Magalhães, 2018) whereas rainfall has both positive (Akram, 2012; Brown, Meeks, Ghile, \& Hunu, 2013; Odusola $\&$ Abidoye, 2015) and negative impacts on economic growth (Dell, Jones, \& Olken, 2012; Tebaldi \& Beaudin, 2016). Until recently, few studies have examined and explored how rainfall is related to economic growth, with research conducted mostly in African countries (Ali, 2012; Barrios, Bertinelli, \& Strobl, 2010; Berlemann \& Wenzel, 2018; Cabral, 2014; Miguel \& Satyanath, 2011; Richardson, 2007; Sebastien, 2010) such as Sub-Saharan Africa where rainfed agriculture is dominant (Borgomeo et al., 2018).

Rainfall is very important for national economies, and this is especially true for agricultural sector as a source of food. In the case of Thailand, precipitation has a major role in the agricultural sector because approximately 13,100 ha of farmland are located away from irrigated areas. This means that $80 \%$ of the country's farmland is dependent on rainfall. Thailand has a serviced-based economy, however the country's agriculture sector is a crucial foundation for the national economy since it employs about 25 million people, or $40 \%$ of the total labour force (The National Statistic Office of Thailand, 2018). Most farmer households are located in the northern, northeastern, and southern (Figure 1), with the majority of farming income, excluding fishery income, coming from the first two regions. Yet the northern and northeastern regions are faced with the lowest incomes and are the driest regions of Thailand. In southern Thailand, most of its agricultural products come from the fishery sector since the area is connected to the sea.

Previous studies have confirmed the negative impact of bad weather shocks on agricultural output (Dell, Jones, \& Olken, 2014), with focus on how temperature affects crop productivity. Evidence suggests that higher 
temperature decreases agricultural yields (Feng, Krueger, \& Oppenheimer, 2010; Guiteras, 2009; Schlenker \& Roberts, 2009). Agricultural-based economies, especially in African countries (Ali, 2012; Lanzafame, 2014; Miguel et al., 2011; Odusola et al., 2015; Richardson, 2007) face arid and semi-arid conditions. Thailand is located in tropical areas as an upper-middle income service-based economy. The country differs from previous studies in terms of volume of rainfall, income level and national economic characteristics.

This study focuses on rainfall which varies in each region. Highest rainfall is in the southern region while the driest areas are in the northern and northeastern which also have the lowest income. Average temperature is stable at around $21-29^{\circ} \mathrm{C}$. The research assumption of this study is that rainfall may affect economic growth rather than temperature. Therefore, rainfall is the variable of interest, with temperature as a control variable. The purpose of this study was to investigate how rainfall affects Thai economic growth by region via a detailed examination of individual agricultural sector as rainfall is extremely important to agriculture. Additionally, the present study focused on the agricultural sector since the results show that rainfall only has a positive impact in poor and dry Thai regions where there is a heavy economic focus on farming. Previous studies in African countries suggested that poor and arid areas mostly depend on agriculture (Ali, 2012; Miguel et al., 2011). This evidence therefore inspired the researchers to concentrate on the agricultural sector in Thailand. Another study objective was to provide further evidence that rainfall impacts the agricultural subsector, both in terms of farmland and fishing. The present study adds to the existing literature since previous studies on the economic impact of precipitation have focused only on farmland rather than for the fishing sector. The researchers' fundamental assumption was that precipitation has a positive effect in rainfed-agricultural areas, which are typically located in arid and poor regions. An economic growth model was developed that incorporates rainfall and temperature as a climatic variable in the production function, while the FGLS estimator was adopted to analyse panel data across of Thailand's 76 provinces which were separated to seven regions, with data coming from the period 2004 to 2015.

Three major conclusions were drawn. Firstly, rainfall has a significant positive impact on gross provincial product (GPP) growth in northern and northeastern regions of Thailand. Moreover, all the macroeconomic variables were found to be consistent with what would be expected for the economic growth theory whenever these variables are significant. Secondly, rainfall is again found to have a strong and significant positive impact on agricultural growth within both of these regions. Thirdly, two agricultural subsectors as farming and fishing were affected by rainfall with fishing activities in many regions showing greater influence from rainfall than farming. These divergent results confirm that Thailand's northeastern and northern regions economically benefit the most from rainfall while fishing plays a major role instead of farming. Thus, these findings contribute to the existing literature by shedding light on how rainfall impacts on aggregate economic growth and agricultural growth at sector and subsector level. Results also indicate deep spatial differences between regions which have important implications regarding how the government should support regional agricultural activities, especially during predictable rainy seasons. Finally, our findings may motivate similar research in other developing countries in the region.

Our paper is structed as follows. The next section reviews the existing literature concerning how precipitation can affect economic growth. This followed by a review of the background theory which is applied to the empirical model using data sources and summary variables. Discussion and estimated specification are presented in section 4 , followed by the conclusions which are drawn in section 5 . 


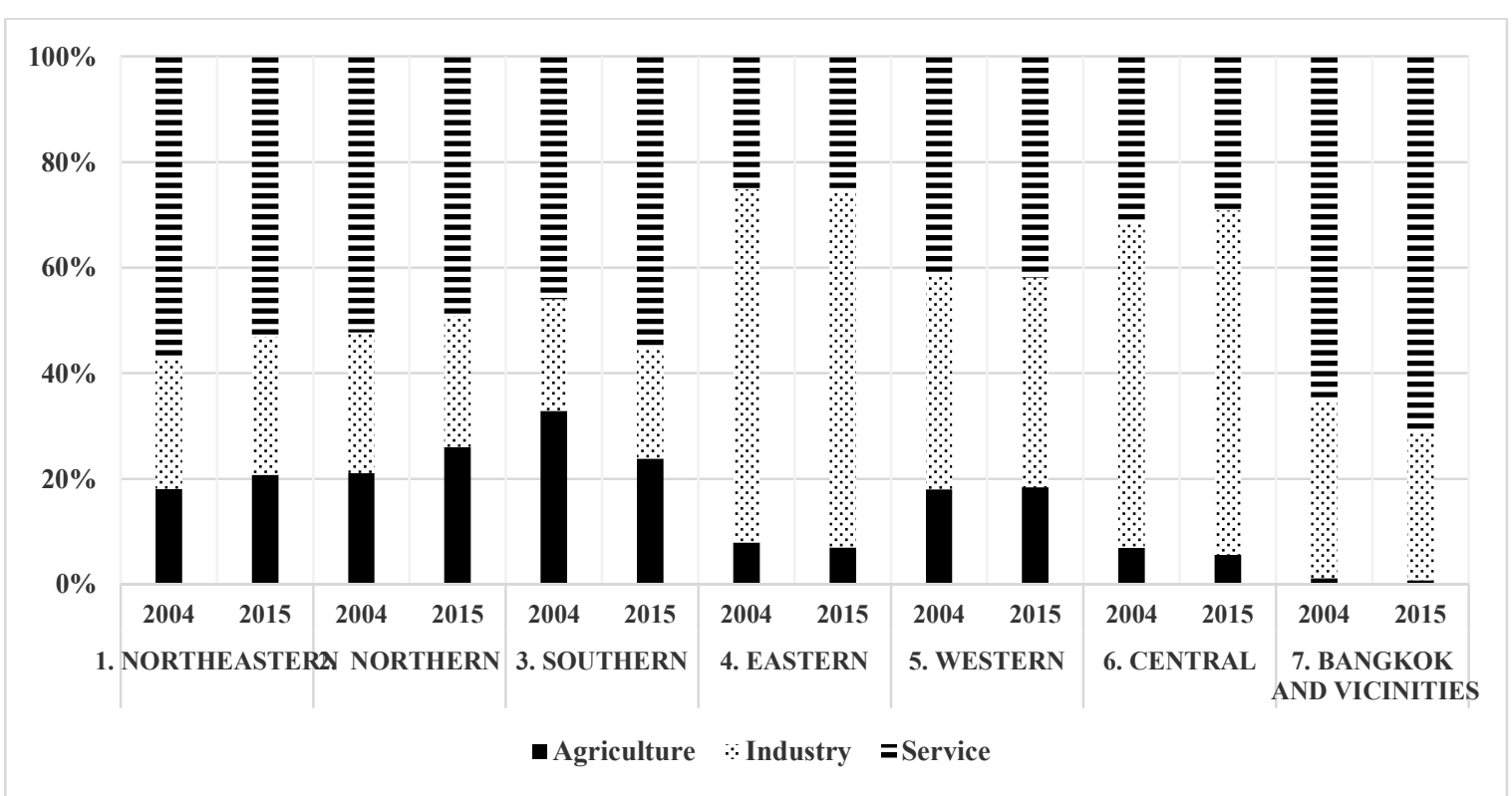

Figure 1. Share of Gross Regional Product by sector in 2004 and 2015 across 7 regions.

\section{Literature Review}

Most of the existing literature focused on how climate change impacted on economic growth by considering temperature and rainfall as climatic variables. Discussion concentrated on expected increases in average national temperatures.For example, higher temperatures were forecast to reduce income, particularly in developing countries (Dell, Jones, \& Olken, 2009; Dell et al., 2012; Horowitz, 2009). Recent studies explored how rainfall impacted on economic growth and focused on countries with rainfed agriculture. African countries were widely studied with general overall agreement that rainfall positively affected economic growth (Abidoye \& Odusola, 2015; Lanzafame, 2014; Miguel et al., 2011; Sequeira et al., 2018).

There is a natural relationship between the environment and agricultural productivity, with temperature and water as direct inputs into the biological process of plant growth. Therefore, agriculture has been the main focus of research on climate change. Impacts on developing countries were estimated using a panel data model, with results confirming the negative consequences of bad weather on agricultural output (Dell et al., 2014). Schlenker and Lobell (2010) used weather fluctuations to measure a model of yield response in sub-Saharan Africa. They found that higher temperatures generally reduced yields, while Guiteras (2009) estimated that higher temperatures in a given year reduced agricultural output in India and Feng et al. (2010) reported that high temperatures reduced agricultural output at the state level in Mexico. In case of rainfall, Gadgil and Gadgil (2006) observed that rainfall deficiency had a greater negative impact on GDP and grain production compared to surplus rainfall in India. In the same vein, Lertamphainont and Sparrow (2016) noted that crop income fell sharply due to rainfall extremes from either flood or droughts in Thailand, while Levine and Yang (2014) showed that higher rainfall led to increased rice production using a panel of Indonesian districts. Rainfall, typically, had a positive impact on production yield (Dkhar, Feroze, Singh, \& Ray, 2017; Isik \& Devadoss, 2006). For instance, rainfall positively affected cassava yield in northeastern areas of Thailand which is a poor region (Phatcharopaswatanagul, 2018) consistent with Dell et al. (2012) who found that precipitation positively affected agricultural output in poor countries.

However, few in-depth studies have investigated the impact of climatic variables on economic growth by sector. Akram (2012) determined that annual rainfall had a significant positive impact on the agricultural and manufacturing sectors but did not influence the service sector. Sebastien (2010) found that rainfall deviations had a greater impact on agricultural economic growth compared to urban economic growth, while Loayza, Olaberria, Rigolini, and Christiaensen (2012) examined how natural disasters affected economic sector growth. They concluded that disasters have the potential to affect economic growth but not always in a negative manner. For example, moderate flooding can trigger positive economic growth in the agricultural, industrial and service sectors.Flooding positively affects the agricultural sector since floods are often localised and concentrated in small areas; the floodwater can be used as a plentiful annual water supply for irrigation which improves agricultural productivity.

The existing literature largely considers the relationship between rainfall and economic growth on a macro scale using national data from many different countries. Generally, a positive relationship was found between rainfall and economic outcome with higher rainfall stimulating economic growth, while rainfall reductions 
generally harmed economic growth. Consequently, rainfall variability can both improve and harm economic growth, particularly in poor and arid countries reliant on agriculture. Furthermore, few previous studies have examined rainfall and economic growth at the sector level (agricultural, industrial, service) and ignored subsector levels. In addition, previous studies have mostly concentrated on how rainfall impacts on crop yield and ignored fishing activities. Here, an in-depth examination was presented concerning how both the agricultural sector and agricultural subsectors are influenced by precipitation in different Thai regions. To the best of our knowledge, similar research has not been previously undertaken in Thailand.

\section{Methodology}

Climate has the potential to either reduce or increase the economic fortunes of a country. Most previous studies relied on the Solow-Swan, Ramsey-Cass-Koomans, and Mankiw, Romer and Weil models as the most widely used growth models in the literature for analysing the impact of climate change on economic growth (Zeb, 2013). This study followed the Mankiw, Romer, and Weil (1992) theoretical model, developed from the Solow growth model (Solow, 1956) by adding human capital variables into production functions.

Moreover, Dell et al. (2012) incorporated climatic variables in the production function. These were also used as the baseline for our study. Based on simple production function, total factor productivity (TFP) is also affected since climate is assumed to have an influence on productivity. The climate variable of rainfall was added directly in the model as an additional factor which was then used to explain economic performance. Our primary goal was to investigate whether rainfall impacted on national economic growth by region in Thailand.

\subsection{Empirical model}

Consistent with description of Mankiw, Romer and Weil theoretical model, the empirical model specified use with the variable of rainfall introduced as an added growth model determinant. The feasible generalized least square (FGLS) approach was used to estimate panel data.

This paper focused on three primary livelihood indicators as our outcome variables: (i) GPP per capita growth, (ii) agriculture GPP per capita growth (sector level) and (iii) agriculture GPP per capita growth (subsector level).

The empirical model was expressed as:

$$
\ln y_{i, t}-\ln y_{i, t-1}=\gamma_{0}+\gamma_{1} \text { rain }_{i, t}+\gamma_{2} \text { temp }_{i, t}+\gamma_{3} \ln \text { gov }_{i, t}+\gamma_{4} \text { pop }_{i, t}+\varepsilon_{i, t}
$$

where $\ln y_{i, t}$ is the natural logarithm of the gross provincial product (GPP) per capita in province $i$ at time

$t$, $\operatorname{rain}_{i, t}$ is the average annual rainfall, temp $_{i, t}$ is the average annual temperature, $\ln g o v_{i, t}$ is the natural logarithm of share of government expenditure in GPP, $p o p_{i, t}$ is the population growth rate, and $\varepsilon_{i, t}$ is the unexplained residual.

Stability testing used the standard set of control variables typically employed in growth regressions as net fertility, education, saving rate and government consumption share (Berlemann \& Wenzel, 2015). In addition, there were researches used population growth (Akram, 2012; Odusola et al., 2015; Zeb, 2013). For the government expenditure share are applied to this study, representing both of human and physical capital. Here, we conduct government expenditure share and population growth used as control variables. The present study also added temperature to the estimated model for a robustness check since the rainfall variable may correlate with temperature (Auffhammer, Hsiang, Schlenker, \& Sobel, 2013).

\subsection{Data type and sources}

This section describes the data sources and procedures used to aggregate data at the provincial level. The empirical study relied on panel data sets collected from different Thai government organisations between 2004 and 2015 across 76 provinces and then the researchers classified all these provinces to 7 regions based on Office of the National Economic and Social Development Board of Thailand.

- Weather station data collected by the Thai Meteorological Department (TMD). This dataset reports average daily data across 129 Thai weather stations. The longest common sample across all weather station runs from 1995 to 2015. However, we only used data between 2004 and 2015 to match with the government expenditure records. Average annual rainfall (in millimeters) and annual temperature (Celsius) were used and calculated using average monthly data. Temperature was included here as a robustness check.

- GDP at provincial level data. We used data of real GDP by province (also known as gross provincial product (GPP) in Thailand), using Chain Volume measures against the reference year 2002. This data set was reported in an annual series in Thai baht. Our research used real GPP which was collected by the Office of the National Economic and Social Development Board of Thailand.

- Government expenditure data. Thailand started collecting provincial data in 2004. Our research used government expenditure share in GPP at a nominal price. 
- $\quad$ Population data was collected from the Department of Provincial Administration of Thailand. The data set was reported in an annual series. The research used population growth rate in an annual series. Table 1. Summary statistics of the variables

\begin{tabular}{lcrrrr}
\multicolumn{1}{c}{ Variable } & Obs & \multicolumn{1}{c}{ Mean } & \multicolumn{1}{c}{ Std. Dev. } & \multicolumn{1}{l}{ Min } & \multicolumn{1}{c}{ Max } \\
\hline Farming per capita growth & 912 & 0.000 & 0.106 & -1.67 & 0.32 \\
Fishing per capita growth & 912 & -0.014 & 0.194 & -0.81 & 1.17 \\
Agriculture per capita growth & 912 & 0.002 & 0.106 & -1.65 & 0.63 \\
GPP per capita growth & 912 & 0.024 & 0.061 & -0.39 & 0.35 \\
Annual average rainfall $(100 \mathrm{~mm} /$ year $)$ & 912 & 1.320 & 0.661 & 0.43 & 5.39 \\
Annual average temperature $\left({ }^{\circ} \mathrm{C}\right)$ & 912 & 27.495 & 1.085 & 21.06 & 29.60 \\
Government expenditure share & 912 & -3.113 & 0.834 & -6.36 & -1.26 \\
Population growth rate & 912 & 0.004 & 0.013 & -0.06 & 0.15 \\
\hline
\end{tabular}

Note: All growth variables and government expenditure share are in natural logs, except population growth rate

\section{Estimation of results and discussion}

This section presents the results and analysis the impacts of rainfall on GPP growth by regions. Macroeconomic factors are often found to be non-stationary (Alagidede, Adu, \& Frimpong, 2015). Thus, panel unit root tests were conducted to determine their order of integration. Next, we applied panel heteroscedasticity test to investigate stationary variance of the error term. These two tests are suitable to check all variables and models. In the final step, we estimated the model using efficient techniques.

\subsection{Panel Unit Root Test}

This study followed quantitative analysis procedures. Firstly, the panel unit root test was used to determine whether the variables were stationary or non-stationary at the same level. This study utilised three district panel unit root tests for the 2004-2015 period and 7 regions, considering from 76 provinces of Thailand. As the CIPS; Z t-bar statistic, ADF-Fisher; Z statistic and Breitung; lambda statistic. Among these, the Breitung tests are based on the common unit root process assumption which autocorrelation coefficients of tested variables are identical across cross sections, while the ADF-Fisher and CIPS test rely on the individual unit root process assumption that autocorrelation coefficients vary across cross sections.

Test results showed that all GPP per capita growth variables are stationary in the CIPS test, except region 7, while there are three independent variables as temperature, government expenditure share and population growth are not stationary in certain regions. Using an alternative test; temperature and population growth were stationary in the ADF-Fisher test. Government expenditure in all regions were stationary in Breitung test. As a result, statistical significance was shown for all variables, suggesting no unit root test in panel data; thus, all variables can be estimated for panel data model (see Table A3).

\subsection{Panel Heteroskedasticity Test}

Heteroskedasticity refers to the situation in which the variance of the error term is not constant. According to James and Mark (2011) indicate that if the regression error is heteroskedastic, standard errors are not a reliable basis for hypothesis tests and confidence intervals, while Wooldridge (2015) states that if regression disturbance are homoscedastic with the same variance across time and individuals, then this may be a restrictive assumption for panels.

Here, by applying the White test, most regressions showed homoscedasticity while some regressions exhibited heteroscedasticity; table 2 in region 3, and table 2 in region 3, 5 and 7 . Thus, to overcome this issue we used the feasible generalized least squares (FGLS) estimator to estimate the growth model as a result no autocorrelation and multicollinearity were found in our data.

\subsection{Estimation and interpretation}

Before estimating the empirical model, the unit root test was used to test whether variables are stationary or nonstationary. Results showed that all variables are stationary, after removing the educational variable, to provide the reliable estimation. In addition, to conduct more comprehensive empirical work we attempted to overcome the heteroskedasticity problem. To achieve this, we employed the FGLS estimator to fit panel data in all models.

This research study shows how rainfall affects on GPP growth by regions. In this study 7 regions were considered from all across the kingdom of Thailand. There were 3 steps of study. First, rainfall effects were investigated at the national level, in which the results revealed that rainfall had a significant positive impact on GPP growth in two regions, which are northeastern and northern (see Table A1), these two regions faced with the lowest income and the driest areas of Thailand. In addition, these areas are mainly agricultural base, the most income of the Thai agricultural sector comes from these two areas, exclude fishing, which corresponded to Ali 
(2012) found that Ethiopia is totally dependent on rainfed agriculture and lack of precipitation has a negative impact on economic growth. Based on the results found that rainfed agriculture areas have been affected significantly by rainfall, which inspire our research focus on the agriculture sector. The researchers investigated in which region rainfall has more effects on agricultural growth (step 2). Again, the results indicated that there are these two regions in which agricultural growth have been affected significantly by rainfall. In addition, Bangkok and vicinities (region 7) were affected by rainfall positively (see Table A2). Therefore, we further elaborate our study in order to determine whether rainfall has impacted on agriculture subsectors (step 3).

Two sub-agriculture sectors and seven regions were considered. The results showed statistically significant that both two subsectors and five regions have been affected by rainfall. Interestingly, the evidence showed that rainfall has significant affected on fishing in many regions than farming subsectors. The first subsector was farming ${ }^{1}$ which was only this region, northern, that rainfall effects on (Table 2). The second subsector, which included northeastern, northern, southern, western and Bangkok and vicinities, was fishing that rainfall has affected on (Table 3). The reason to explain why rainfall has affected on agricultural growth in these five regions as follows.

One of the reasons why rainfall has a positive strong and significant effects on the northern of Thailand is that because Thailand's farming income, excluding fishing, mostly comes from this area, however, this area is arid and rather poor. The results implied that the agricultural production will increase in this area in the rainy season more than other seasons leading to arise in the number of seasonal workers. According to the Cobb-Dauglas production function, the amount of output that can be produced depends on the extent to which labor input is utilized to generate sustainable output. In addition, economic crops of northern of Thailand are rice, cassava and corn. Having said that, rice and cassava are the top 3 agricultural export products of Thailand (MOC, 2015). Among this, rice is the major crop in this region. Thailand also is the world's second largest rice export market, yet India takes the lead in rice export. Base on the data obtained in between the years of 2004-2015, the most of rice income comes from the northern of Thailand in 2008 and 2012-2014, the second region, however is northeastern (see Figure B2). The majority of rice in Thailand is produced in rainfed condition while irrigated water is supplied to rice growing in the dry season (Shrestha et al. 2017). As a result, rainfall is an important factor in the rice growing. Correspondingly, Sinnarong et al. (2018) found that the precipitation increase are directly proportional with the increase of rice production levels in Thailand. In addition, since northern Thailand is a very dried area, and rather poor, the region has the second lowest of gross regional product (GRP), the lowest income, however, is in the northeastern. These are consistent with previous studies conducted, showing that in dry and poor countries mostly in African countries, precipitation had a positive effect on economic growth (Lanzafame, 2014; Miguel et al., 2011; Odusola et al., 2015) because these countries have rainfed agriculture. Based on this example, we can say that precipitation has a positive impact on farming growth because northern Thailand has agriculturebased economy in which rainfed agriculture regions play a crucial role.

Secondly, rainfall has both positive and negative effect on the fishery subsector in five regions and a positive impact on fishing activities in three regions. The northeastern, northern, and Bangkok and vicinities regions have abundant water resources as rivers and dams and rainfall stimulates fish spawning as one of the major climatic factors influencing water chemistry in the wetlands, triggering many fish species to spawn (Karnatak et al., 2018). According to Bruton (1979) catfish spawning occurs at night, usually after heavy rainfall in freshly inundated marginal areas, and Grass Carp fish also lay eggs after raining, which is consistent with Sharma et al. (2014), who found that the duration of breeding (number of days) in major fish species in inland water increases with the increase in the number of rainy days. Moreover, Stacey (1984) reported that freshwater and floods are important to stimulate tropical fish spawning, especially when the rainy season or the flood season makes fish breeders to breed tropical fish in flooded areas. Woynarovich and Horváth (1980) found that freshwater has better effects on fish breeding. Since in the rainy season, the water levels and density of the rivers and canals in the regions are higher, water overflows onto the banks, paving the way for flooding on the fields, forming swamps and streams, all these areas are connected to one another are called flood plains. Another reason to explain why rainfall has positive effects on the fishery subsector in the northeastern and northern of Thailand is that the Mekong fishery has an importance for household economies in these two areas. The Mekong River is the largest freshwater fishery and the third most bio-diverse river system in the world (Intralawan et al. 2018) and the world's 12th longest river with a total length of 4,800 km and passed through six countries; China, Myanmar, the Lao PDR, Thailand, Cambodia and Viet Nam (Pawaputanon Na Mahasarakarm, 2007), the last four countries are known as the Lower Mekong Basin (LMB) countries. The Mekong river in Thailand is one of the most biologically diverse environments in the world and is home to abundant species. Aquatic creatures, particularly fish, play a major role in the life and livelihoods of the human of the Mekong Basin in Thailand (Pawaputanon Na Mahasarakarm 2007). The Mekong fishery sectors in Thailand is over US\$750 million in 2008 (MRC 2019). The Mekong Basin in Thailand contains a diversity of water bodies including floodplains, tributaries, canals, swamps, and reservoirs;

${ }^{1}$ Farming is defined as agriculture, hunting and forestry. 
the 8,667 rivers, rivulets, and canals; 6,751 swamps and reservoirs; 463 wetlands and lowlands; and 161 other types of water body cover a combined area of 236,000 ha (Pawaputanon Na Mahasarakarm 2007). Having said that, the Mekong river also consists of many water bodies, which can create fish spawning grounds in the rainy season. For example, floodplains are appropriate areas for fish to lay eggs due to when flooding, also, there are organisms in the dry soil stimulating fish to lay eggs (Stacey 1984). Since there are many floodplains all along the Mekong river that are suitable for fish breeding and nursery, the Mekong fishery always has a growing potential in the region (Phomikong et al., 2018). In Bangkok and the immediate vicinities, the Chao Phraya river as the main river of Thailand is an important fishing source. Patrick (2016) reported that heavy rainfall and increasing water level in inland reservoirs are positive cues for fish reproduction. Therefore, precipitation has positive effects on the fisheries subsector in the regions of northeastern, northern, and Bangkok and vicinities regions of Thailand by stimulating aquatic animals to spawn. These three areas also have many water sources for fishing including the Mekong and Chao Phraya rivers. Furthermore, the southern and western regions of Thailand are negatively influenced by rainfall. Most provinces are connected to the sea or located in high rainfall areas. The portion of fishing income of these two areas is high; the first ranked is in the south and the second is western and eastern. Rainfall can be an obstacle for fishing, especially during the rainy season.

As a results rainfall has both positive and negative effects on agricultural activities in different regions depending on the economic characteristic. One interesting result is that rainfall has a greater influence on fishing in many regions of Thailand than farming and only northern region that have affected by rainfall. Thus, the Thai fishing economy plays a major role in the economic impact of precipitation.

Macroeconomic variables considering in main growth model (see Appendix A1) indicated that all macroeconomic variables were in accordance with the economic growth theory. Government share in GPP, representing human and physical capital, gave a negative impact on economic growth (Barro, 1990; Loayza et al., 2012). Population growth was also found to have a negative impact on economic growth (Akram, 2012; Coale \& Hoover, 1958). For the agricultural two-subsector growth model, macroeconomic variables were still shown the right sign whenever these variables were significant (Table 2, 3). For example, population growth has a negative impact on agricultural growth which is the source of food. This confirm that the research's models are robust. Table 2 Farming subsector growth model. Sample: 76 provinces, 7 regions, 2004-2015; Estimation method: FGLS

\begin{tabular}{|c|c|c|c|c|c|c|c|}
\hline & \multicolumn{7}{|c|}{ Dependent variables: GPP per capita growth } \\
\hline & $\begin{array}{c}\text { (1) } \\
\text { Northeastern }\end{array}$ & $\begin{array}{c}\text { (2) } \\
\text { Northern }\end{array}$ & $\begin{array}{c}\text { (3) } \\
\text { Southern }\end{array}$ & $\begin{array}{c}\text { (4) } \\
\text { Eastern }\end{array}$ & $\begin{array}{c}\text { (5) } \\
\text { Western }\end{array}$ & $\begin{array}{c}\text { (6) } \\
\text { Central }\end{array}$ & $\begin{array}{c}\text { (7) } \\
\text { Bangkok \& } \\
\text { Vicinities }\end{array}$ \\
\hline Rainfall & 0.00659 & $0.104^{* *}$ & -0.00274 & 0.00671 & -0.0456 & -0.00922 & -0.00552 \\
\hline Annual average rainfall (100 mm/year) & $(0.0182)$ & $(0.0393)$ & $(0.0099)$ & $(0.0089)$ & $(0.0643)$ & $(0.0603)$ & $(0.0262)$ \\
\hline $\begin{array}{l}\text { Temperature } \\
\text { Annual average temperature }\left({ }^{\circ} \mathrm{C}\right)\end{array}$ & $\begin{array}{l}-0.00955^{*} \\
(0.0045)\end{array}$ & $\begin{array}{l}-0.00761 \\
(0.0098)\end{array}$ & $\begin{array}{l}0.0100 \\
(0.0157)\end{array}$ & $\begin{array}{l}-0.0242 \\
(0.0147)\end{array}$ & $\begin{array}{l}-0.0540^{*} \\
(0.0230)\end{array}$ & $\begin{array}{l}-0.121^{* * *} \\
(0.0295)\end{array}$ & $\begin{array}{l}-0.00946 \\
(0.0148)\end{array}$ \\
\hline $\begin{array}{l}\text { Government expenditure share } \\
\text { Government expenditure/GPP (in logs) }\end{array}$ & $\begin{array}{l}-0.0244 \\
(0.0135)\end{array}$ & $\begin{array}{l}-0.0248 \\
(0.0192)\end{array}$ & $\begin{array}{l}-0.00330 \\
(0.0122)\end{array}$ & $\begin{array}{l}0.0231 * \\
(0.0091)\end{array}$ & $\begin{array}{l}0.0120 \\
(0.0255)\end{array}$ & $\begin{array}{l}-0.0460^{* \star} \\
(0.0164)\end{array}$ & $\begin{array}{l}0.000258 \\
(0.0098)\end{array}$ \\
\hline $\begin{array}{l}\text { Population growth } \\
\text { Population growth rate }\end{array}$ & $\begin{array}{l}0.667 \\
(0.9031)\end{array}$ & $\begin{array}{l}-0.575 \\
(0.5800)\end{array}$ & $\begin{array}{l}-2.315^{* \pi *} \\
(0.5686)\end{array}$ & $\begin{array}{l}2.916^{* * *} \\
(0.8021)\end{array}$ & $\begin{array}{l}-2.999 * \pi * \\
(0.9088)\end{array}$ & $\begin{array}{l}-0.454 \\
(1.3803)\end{array}$ & $\begin{array}{l}-0.285 \\
(0.5663)\end{array}$ \\
\hline White test $\left(\chi^{2}\right)$ & $\begin{array}{l}17.71 \\
(0.2202)\end{array}$ & $\begin{array}{l}4.64 \\
(0.9903)\end{array}$ & $\begin{array}{l}25.92 \\
(0.0265)\end{array}$ & $\begin{array}{l}10.04 \\
(0.7592)\end{array}$ & $\begin{array}{l}7.71 \\
(0.9040)\end{array}$ & $\begin{array}{l}10.08 \\
(0.7566)\end{array}$ & $\begin{array}{l}23.13 \\
(0.0581)\end{array}$ \\
\hline Constant & $\begin{array}{l}0.207 \\
(0.1322)\end{array}$ & $\begin{array}{l}0.0272 \\
(0.2744)\end{array}$ & $\begin{array}{l}-0.272 \\
(0.4258)\end{array}$ & $\begin{array}{l}0.734 \\
(0.4230)\end{array}$ & $\begin{array}{l}1.612 * \\
(0.6898)\end{array}$ & $\begin{array}{l}3.254^{i \dot{*}} \\
(0.8516)\end{array}$ & $\begin{array}{l}0.266 \\
(0.4214)\end{array}$ \\
\hline Observations & 228 & 204 & 168 & 96 & 72 & 72 & 72 \\
\hline Number of provinces & 19 & 17 & 14 & 8 & 6 & 6 & 6 \\
\hline
\end{tabular}

Notes: 1. Standard errors in parentheses.

2. *Significant at $5 \%, * *$ Significant at $1 \%, * * *$ Significant at $0.1 \%$

3. Farming is defined as agriculture, hunting and forestry. 
Table 3 Fishing subsector growth model. Sample: 76 provinces, 7 regions, 2004-2015; Estimation method: FGLS

\begin{tabular}{|c|c|c|c|c|c|c|c|}
\hline & \multicolumn{7}{|c|}{ Dependent variables: GPP per capita growth } \\
\hline & (1) & (2) & (3) & (4) & (5) & (6) & (7) \\
\hline & Northeastern & Northern & Southern & Eastern & Western & Central & $\begin{array}{r}\text { Bangkok \& } \\
\text { Vicinities }\end{array}$ \\
\hline Rainfall & $0.0826^{\star * \pi}$ & $0.108^{*}$ & $-0.0376^{*}$ & 0.0208 & $-0.401^{* * \pi}$ & 0.0868 & $0.203^{* * *}$ \\
\hline $\begin{array}{l}\text { Annual average rainfall }(100 \\
\text { mm/year })\end{array}$ & $(0.0364)$ & $(0.0614)$ & $(0.0211)$ & $(0.0201)$ & $(0.1454)$ & $(0.1109)$ & $(0.0680)$ \\
\hline Temperature & -0.00294 & -0.00764 & -0.0503 & -0.0146 & $-0.155^{\dot{*} * \pi}$ & -0.0460 & -0.0485 \\
\hline Annual average temperature $\left({ }^{\circ} \mathrm{C}\right)$ & $(0.0090)$ & $(0.0153)$ & $(0.0337)$ & $(0.0330)$ & $(0.0521)$ & $(0.0542)$ & $(0.0384)$ \\
\hline Government expenditure share & 0.00176 & 0.0260 & -0.0213 & -0.0141 & 0.107 & 0.0530 & -0.0167 \\
\hline Government expenditure/GPP (in & & & & & & & \\
\hline logs) & $(0.0270)$ & $(0.0301)$ & $(0.0263)$ & $(0.0204)$ & $(0.0577)$ & $(0.0302)$ & $(0.0255)$ \\
\hline Population growth & $-5.236^{* \pi *}$ & -0.940 & 1.021 & -2.162 & -1.391 & -1.637 & 1.381 \\
\hline Population growth rate & (1.8055) & $(0.9061)$ & (1.2198) & (1.8012) & $(2.0544)$ & (2.5387) & (1.4696) \\
\hline Constant & -0.0282 & 0.149 & 1.387 & 0.328 & $5.067^{* * \star}$ & 1.399 & 1.021 \\
\hline & $(0.2642)$ & $(0.4286)$ & $(0.9134)$ & $(0.9500)$ & (1.5593) & $(1.5662)$ & (1.0936) \\
\hline White test $\left(\chi^{2}\right)$ & 12.40 & 6.91 & 23.96 & 11.27 & 25.74 & 10.21 & 27.37 \\
\hline & $(0.5739)$ & $(0.9381)$ & $(0.0463)$ & $(0.6650)$ & $(0.0280)$ & $(0.7465)$ & $(0.0172)$ \\
\hline Observations & 228 & 204 & 168 & 96 & 72 & 72 & 72 \\
\hline Number of provinces & 19 & 17 & 14 & 8 & 6 & 6 & 6 \\
\hline
\end{tabular}

Notes: 1. Standard errors in parentheses.

2. *Significant at $10 \%, * *$ Significant at $5 \%, * * *$ Significant at $1 \%$

\section{Conclusions}

This study investigate how rainfall affected Thai economic growth by region at country level, sector level and subsector level. Considering the 7 regions, we found that rainfall had a significantly positive impact on economic growth at a country level only two regions, which are northeastern and northern. This results were consistent with previous studies which found that rainfall positively impacted on economic growth, mostly in poor and rainfedagricultural countries and particularly in less developed region like northeastern and northern Thailand. In addition, precipitation had a significant positive effect on the agricultural sector. Thus, we determined which sub-agriculture sectors and regions were influenced by rainfall. Results showed two agricultural subsectors and five regions impacted by rainfall as agriculture, hunting and forestry in the northern region, and fishing subsectors in the northern, northeastern, Bangkok and vicinities, southern and western region.

Results indicated that rainfall had a substantial and significant impact on economic growth, especially in poorer areas of northern and northeastern areas of Thailand due to their agriculture-based economy. Furthermore, fishing activities were affected by rainfall in many areas of Thailand including the two poorer regions, where inland fisheries and important water resources such as the Mekong river in particular, lead to more agricultural productivity during the rainy season.

The findings will assist the Thai government to focus on better management on water resources policies in order to support a growing cultivation (e.g. artificial rain, irrigation management) on dried and poor area of Thailand. Moreover, water management is an important tool to increase fisheries production, one approach, used effectively for rivers is artificial floods to enhance natural spawning of migratory species (Welcomme, 2008), it may be achieved in Thailand.

Finally, previous studies determined that the impact of rainfall surplus and deficiency on economic growth are different. For example, the drought index was found to associated with a negative influence on GDP growth, along with flood index but with less magnitude (Brown et al., 2013; Gadgil et al., 2006). In addition, this study demonstrates the additional rainfall information in geography, divided to 7 regions due to each region being different in terms of income and volume of rainfall. Future work should focus on in-depth studies of rainfall shocks, drought and flood indices. A detailed understanding of which rainfall index would impact on economic growth, especially can lead to the implementation of more effective policy decisions by the government. 


\section{Appendix A}

Table A1. Main growth model. Sample: 76 provinces, 7 regions, 2004-2015; Estimation method: FGLS

\begin{tabular}{|c|c|c|c|c|c|c|c|}
\hline & \multicolumn{7}{|c|}{ Dependent variables: GPP per capita growth } \\
\hline & $\begin{array}{c}\text { (1) } \\
\text { Northeastern }\end{array}$ & $\begin{array}{c}(2) \\
\text { Northern }\end{array}$ & $\begin{array}{c}\text { (3) } \\
\text { Southern }\end{array}$ & $\begin{array}{c}(4) \\
\text { Eastern }\end{array}$ & $\begin{array}{c}\text { (5) } \\
\text { Western }\end{array}$ & $\begin{array}{c}(6) \\
\text { Central }\end{array}$ & $\begin{array}{c}\text { (7) } \\
\text { Bangkok \& } \\
\text { Vicinities }\end{array}$ \\
\hline $\begin{array}{l}\text { Rainfall } \\
\text { Annual average rainfall }(100 \mathrm{~mm} / \text { year })\end{array}$ & $\begin{array}{l}0.0210^{*} \\
(0.0094)\end{array}$ & $\begin{array}{l}0.0330^{\star} \\
(0.0157)\end{array}$ & $\begin{array}{l}-0.000282 \\
(0.0069)\end{array}$ & $\begin{array}{l}0.00223 \\
(0.0086)\end{array}$ & $\begin{array}{l}-0.0330 \\
(0.0316)\end{array}$ & $\begin{array}{l}0.0267 \\
(0.0461)\end{array}$ & $\begin{array}{l}-0.0417 \\
(0.0245)\end{array}$ \\
\hline $\begin{array}{l}\text { Temperature } \\
\quad \text { Annual average temperature }\left({ }^{\circ} \mathrm{C}\right)\end{array}$ & $\begin{array}{l}0.00197 \\
(0.0023)\end{array}$ & $\begin{array}{l}-0.00331 \\
(0.0039)\end{array}$ & $\begin{array}{l}0.0210 \\
(0.0110)\end{array}$ & $\begin{array}{l}0.0230 \\
(0.0142)\end{array}$ & $\begin{array}{l}-0.00258 \\
(0.0113)\end{array}$ & $\begin{array}{l}0.00164 \\
(0.0225)\end{array}$ & $\begin{array}{l}0.0298^{*} \\
(0.0139)\end{array}$ \\
\hline $\begin{array}{l}\text { Government expenditure share } \\
\text { Government expenditure/GPP (in logs) }\end{array}$ & $\begin{array}{l}-0.0318^{* * *} \\
(0.0070)\end{array}$ & $\begin{array}{l}-0.0216^{* *} \\
(0.0077)\end{array}$ & $\begin{array}{l}-0.0197^{*} \\
(0.0086)\end{array}$ & $\begin{array}{l}-0.0147 \\
(0.0088)\end{array}$ & $\begin{array}{l}-0.00553 \\
(0.0125)\end{array}$ & $\begin{array}{l}-0.0408^{* *} \\
(0.0125)\end{array}$ & $\begin{array}{l}0.00848 \\
(0.0092)\end{array}$ \\
\hline $\begin{array}{l}\text { Population growth } \\
\text { Population growth rate }\end{array}$ & $\begin{array}{l}-0.456 \\
(0.4674)\end{array}$ & $\begin{array}{l}-0.503^{\star} \\
(0.2316)\end{array}$ & $\begin{array}{l}-0.455 \\
(0.3989)\end{array}$ & $\begin{array}{l}-1.733^{*} \\
(0.7758)\end{array}$ & $\begin{array}{l}-1.780^{\star \star \star *} \\
(0.4470)\end{array}$ & $\begin{array}{l}-2.069 * \\
(1.0554)\end{array}$ & $\begin{array}{l}-0.968 \\
(0.5299)\end{array}$ \\
\hline Constant & $\begin{array}{l}-0.125 \\
(0.0684)\end{array}$ & $\begin{array}{l}0.0146 \\
(0.1096)\end{array}$ & $\begin{array}{l}-0.622^{*} \\
(0.2987)\end{array}$ & $\begin{array}{l}-0.661 \\
(0.4091)\end{array}$ & $\begin{array}{l}0.105 \\
(0.3393)\end{array}$ & $\begin{array}{l}-0.195 \\
(0.6511)\end{array}$ & $\begin{array}{l}-0.732 \\
(0.3943)\end{array}$ \\
\hline White test $\left(\chi^{2}\right)$ & $\begin{array}{l}31.51 \\
(0.0047)\end{array}$ & $\begin{array}{l}7.21 \\
(0.9262)\end{array}$ & $\begin{array}{l}24.47 \\
(0.0401)\end{array}$ & $\begin{array}{l}21.54 \\
(0.0885)\end{array}$ & $\begin{array}{l}10.72 \\
(0.7079)\end{array}$ & $\begin{array}{l}14.64 \\
(0.4029)\end{array}$ & $\begin{array}{l}15.77 \\
(0.3276)\end{array}$ \\
\hline Observations & 228 & 204 & 168 & 96 & 72 & 72 & 72 \\
\hline Number of provinces & 19 & 17 & 14 & 8 & 6 & 6 & 6 \\
\hline
\end{tabular}

Notes: 1. Standard errors in parentheses.

2. *Significant at $5 \%, * *$ Significant at $1 \%, * * *$ Significant at $0.1 \%$

Table A2. Agricultural sector growth model. Sample: 76 provinces, 7 regions, 2004-2015; Estimation method: FGLS

\begin{tabular}{|c|c|c|c|c|c|c|c|}
\hline & \multicolumn{7}{|c|}{ Dependent variables: GPP per capita growth } \\
\hline & (1) & (2) & (3) & (4) & (5) & (6) & (7) \\
\hline & Northeastern & Northern & Southern & Eastern & Western & Central & $\begin{array}{c}\text { Bangkok \& } \\
\text { Vincities }\end{array}$ \\
\hline Rainfall & $0.0523^{* *}$ & $0.105^{* *}$ & -0.0126 & 0.00863 & -0.0728 & -0.0106 & $0.0818^{\star}$ \\
\hline Annual average rainfall (100 mm/year) & $(0.0178)$ & $(0.0388)$ & $(0.0095)$ & $(0.0077)$ & $(0.0646)$ & $(0.0593)$ & $(0.0390)$ \\
\hline Temperature & $-0.00931^{*}$ & -0.00771 & -0.0112 & -0.0211 & $-0.0698^{* \pi}$ & $-0.119 * \pi *$ & -0.0408 \\
\hline Annual average temperature $\left({ }^{\circ} \mathrm{C}\right)$ & $(0.0044)$ & $(0.0097)$ & $(0.0151)$ & $(0.0126)$ & $(0.0232)$ & $(0.0290)$ & $(0.0220)$ \\
\hline Government expenditure share & $-0.0405^{* *}$ & -0.0235 & -0.0130 & $0.0184^{*}$ & 0.0227 & $-0.0430^{\star *}$ & 0.0142 \\
\hline Government expenditure/GPP (in logs) & $(0.0132)$ & $(0.0190)$ & $(0.0118)$ & $(0.0078)$ & $(0.0256)$ & $(0.0161)$ & $(0.0146)$ \\
\hline Population growth & 1.107 & -0.618 & -0.459 & $2.099 * *$ & $-2.438 * *$ & -0.445 & 0.245 \\
\hline Population growth rate & $(0.8808)$ & $(0.5717)$ & $(0.5472)$ & $(0.6912)$ & $(0.9132)$ & (1.3582) & $(0.8422)$ \\
\hline \multirow[t]{2}{*}{ Constant } & 0.110 & 0.0319 & 0.293 & 0.634 & $2.118^{* *}$ & $3.198^{* * *}$ & 1.105 \\
\hline & $(0.1289)$ & $(0.2704)$ & $(0.4098)$ & $(0.3645)$ & $(0.6931)$ & $(0.8379)$ & $(0.6268)$ \\
\hline \multirow[t]{2}{*}{ White test 0} & 16.28 & 4.66 & 51.93 & 9.65 & 9.10 & 10.09 & 17.36 \\
\hline & $(0.2964)$ & $(0.9900)$ & $(0.0000)$ & $(0.7875)$ & $(0.8244)$ & $(0.7555)$ & $(0.2376)$ \\
\hline Observations & 228 & 204 & 168 & 96 & 72 & 72 & 72 \\
\hline Number of provinces & 19 & 17 & 14 & 8 & 6 & 6 & 6 \\
\hline
\end{tabular}

Notes: 1. Standard errors in parentheses

2. *Significant at $5 \%, * *$ Significant at $1 \%, * * *$ Significant at $0.1 \%$ 
Table A3. Panel Unit root test results

\begin{tabular}{|c|c|c|c|c|c|c|c|}
\hline \multirow[b]{2}{*}{ Series name } & \multicolumn{7}{|c|}{ Cross-sectionally augmented Im-Pesaran-Shin (CIPS): Zt-bar stat: $\mathrm{H}_{0}=$ non-stationary of the series } \\
\hline & $\begin{array}{c}\text { (1) } \\
\text { Northeastern }\end{array}$ & $\begin{array}{c}(2) \\
\text { Northern }\end{array}$ & $\begin{array}{c}\text { (3) } \\
\text { Southern }\end{array}$ & $\begin{array}{c}(4) \\
\text { Eastern }\end{array}$ & $\begin{array}{c}\text { (5) } \\
\text { Western }\end{array}$ & $\begin{array}{c}(6) \\
\text { Central }\end{array}$ & $\begin{array}{c}(7) \\
\text { Bangkok \& } \\
\text { Vicinities }\end{array}$ \\
\hline \multicolumn{8}{|l|}{ Subsector level } \\
\hline Farming per capita growth & $\begin{array}{l}-9.383 \\
(0.000)\end{array}$ & $\begin{array}{l}-6.622 \\
(0.000)\end{array}$ & $\begin{array}{l}-7.265 \\
(0.000)\end{array}$ & $\begin{array}{l}-7.428 \\
(0.000)\end{array}$ & $\begin{array}{l}-3.879 \\
(0.000)\end{array}$ & $\begin{array}{l}-4.157 \\
(0.000)\end{array}$ & $\begin{array}{l}-3.09 \\
(0.001)\end{array}$ \\
\hline Fishing per capita growth & $\begin{array}{l}-6.567 \\
(0.000)\end{array}$ & $\begin{array}{l}-7.907 \\
(0.000)\end{array}$ & $\begin{array}{l}-6.223 \\
(0.000)\end{array}$ & $\begin{array}{l}-4.465 \\
(0.000)\end{array}$ & $\begin{array}{l}-6.987 \\
(0.000)\end{array}$ & $\begin{array}{l}-4.39 \\
(0.000)\end{array}$ & $\begin{array}{l}-3.354 \\
(0.000)\end{array}$ \\
\hline \multicolumn{8}{|l|}{ Sector level } \\
\hline Agriculture per capita growth & $\begin{array}{l}-9.495 \\
(0.000)\end{array}$ & $\begin{array}{l}-6.619 \\
(0.000)\end{array}$ & $\begin{array}{l}-6.349 \\
(0.000)\end{array}$ & $\begin{array}{l}-6.82 \\
(0.000)\end{array}$ & $\begin{array}{l}-1.593 \\
(0.056)\end{array}$ & $\begin{array}{l}-4.001 \\
(0.000)\end{array}$ & $\begin{array}{l}-2.056 \\
(0.020)\end{array}$ \\
\hline \multicolumn{8}{|l|}{ National level } \\
\hline GPP per capita growth & $\begin{array}{l}-6.309 \\
(0.000)\end{array}$ & $\begin{array}{l}-5.613 \\
(0.000)\end{array}$ & $\begin{array}{l}-5.084 \\
(0.000)\end{array}$ & $\begin{array}{l}-4.561 \\
(0.000)\end{array}$ & $\begin{array}{l}-3.591 \\
(0.000)\end{array}$ & $\begin{array}{l}-3.686 \\
(0.000)\end{array}$ & $\begin{array}{l}-0.734 \\
(0.231)\end{array}$ \\
\hline $\begin{array}{l}\text { Rainfall } \\
\text { Annual average rainfall (mm) }\end{array}$ & $\begin{array}{l}-7.458 \\
(0.000)\end{array}$ & $\begin{array}{l}-3.189 \\
(0.000)\end{array}$ & $\begin{array}{l}-7.338 \\
(0.000)\end{array}$ & $\begin{array}{l}-2.7 \\
(0.003)\end{array}$ & $\begin{array}{l}-2.621 \\
(0.004)\end{array}$ & $\begin{array}{l}-2.342 \\
(0.010)\end{array}$ & $\begin{array}{l}-2.231 \\
(0.013)\end{array}$ \\
\hline $\begin{array}{l}\text { Temperature } \\
\text { Annual average temperature }\left({ }^{\circ} \mathrm{C}\right)\end{array}$ & $\begin{array}{l}-1.051 \\
(0.147)\end{array}$ & $\begin{array}{l}-2.406 \\
(0.008)\end{array}$ & $\begin{array}{l}-3.88 \\
(0.000)\end{array}$ & $\begin{array}{l}-2.315 \\
(0.010)\end{array}$ & $\begin{array}{l}-1.21 \\
(0.113)\end{array}$ & $\begin{array}{l}-0.371 \\
(0.355)\end{array}$ & $\begin{array}{l}-1.198 \\
(0.116)\end{array}$ \\
\hline $\begin{array}{l}\text { Government expenditure share } \\
\text { Government expenditure/GPP (in logs) }\end{array}$ & $\begin{array}{l}-5.781 \\
(0.000)\end{array}$ & $\begin{array}{l}-1.035 \\
(0.150)\end{array}$ & $\begin{array}{l}-0.681 \\
(0.248)\end{array}$ & $\begin{array}{l}-0.081 \\
(0.468)\end{array}$ & $\begin{array}{l}-1.98 \\
(0.024)\end{array}$ & $\begin{array}{l}-0.093 \\
(0.463)\end{array}$ & $\begin{array}{l}-0.337 \\
(0.368)\end{array}$ \\
\hline $\begin{array}{l}\text { Population growth } \\
\text { Population growth rate }\end{array}$ & $\begin{array}{l}-5.621 \\
(0.000)\end{array}$ & $\begin{array}{l}-13.166 \\
(0.000)\end{array}$ & $\begin{array}{l}-5.837 \\
(0.000)\end{array}$ & $\begin{array}{l}-1.86 \\
(0.031)\end{array}$ & $\begin{array}{l}-6.021 \\
(0.000)\end{array}$ & $\begin{array}{l}-1.443 \\
(0.075)\end{array}$ & $\begin{array}{l}-0.521 \\
(0.301)\end{array}$ \\
\hline
\end{tabular}

Table A3. Panel Unit root test results (continued)

\begin{tabular}{|c|c|c|c|c|c|c|c|}
\hline & \multicolumn{7}{|c|}{ Augmented Dicky-Fuller (ADF): Z-stat: $\mathbf{H}_{0}=$ unit root } \\
\hline & Region & Region & Region & Region & Region & Region & Region \\
\hline & 1 & 2 & 3 & 4 & 5 & 6 & 7 \\
\hline GPP per capita growth & & & & & & & -6.9796 \\
\hline & & & & & & & $(0.000)$ \\
\hline Temperature & -14.7914 & & & & -7.432 & -8.8964 & -6.0506 \\
\hline Annual average temperature $\left({ }^{\circ} \mathrm{C}\right)$ & $(0.000)$ & & & & $(0.000)$ & $(0.000)$ & $(0.000)$ \\
\hline Government expenditure share & & 0.8365 & 0.7302 & 0.0173 & & -0.5635 & -0.1156 \\
\hline \multirow[t]{2}{*}{ Government expenditure/GPP (in logs) } & & $(0.7986)$ & $(0.7674)$ & $(0.5069)$ & & $(0.2865)$ & $(0.454)$ \\
\hline & \multicolumn{7}{|c|}{ Breitung: lambda stat: $\mathrm{H}_{0}=$ unit root } \\
\hline Government expenditure share & & -4.9276 & -2.5095 & -3.1447 & & -2.8354 & -1.7807 \\
\hline Government expenditure/GPP (in logs) & & $(0.000)$ & $(0.006)$ & $(0.0008)$ & & $(0.0023)$ & $(0.0375)$ \\
\hline
\end{tabular}

\section{Appendix B}

Table B1. Subsector definition

\begin{tabular}{ll}
\hline Agriculture activities & \multicolumn{1}{c}{ Definition } \\
\hline 1.Agriculture, hunting and forestry & $\begin{array}{l}\text { Division 01 Agriculture, hunting and related service activities } \\
\text { Division 02 Forestry, logging and related service activities }\end{array}$ \\
\hline 2. Fishing & $\begin{array}{l}\text { Division 05 Fishing, operation of fish hatcheries and fish farms; } \\
\text { service activities incidental to fishing }\end{array}$ \\
\hline Source: United Nations Statistics Division (1986)
\end{tabular}


Figure B2. Gross Regional Product (GRP) of rice by region in Thailand

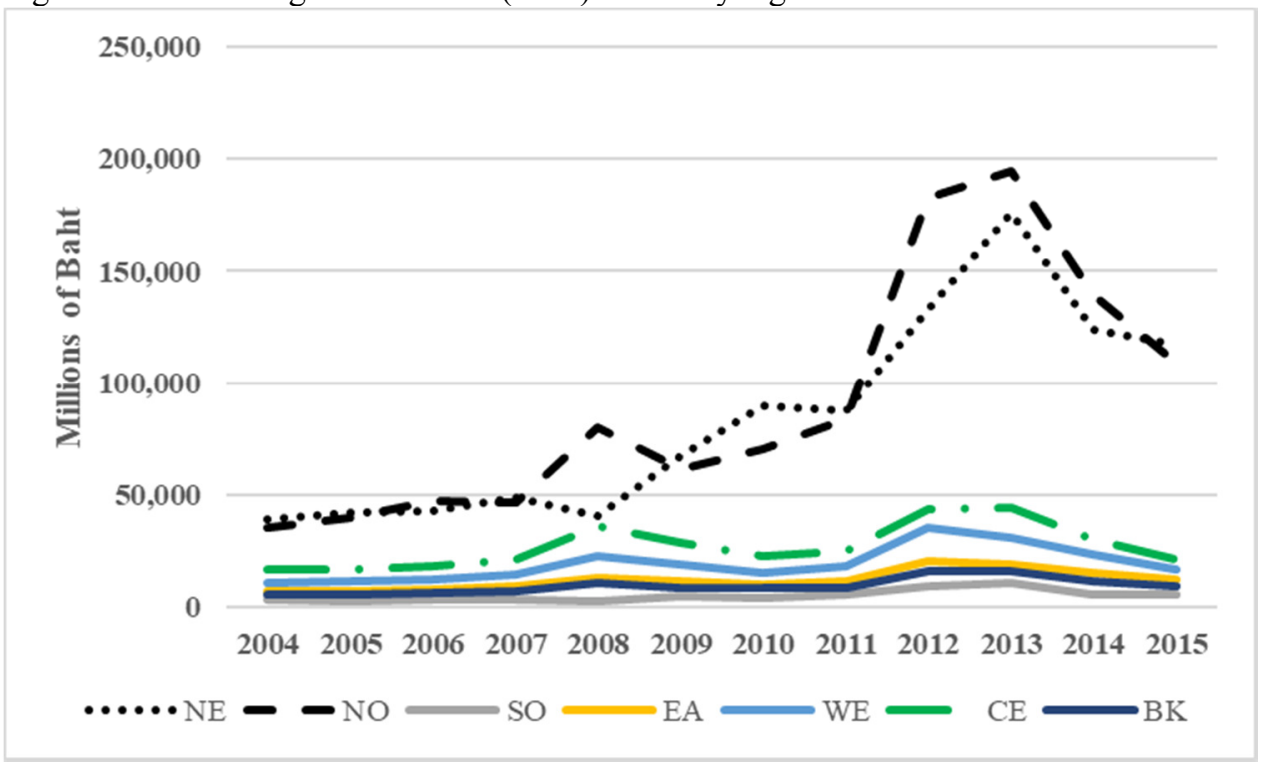

Note: Calculated from National Account of Thailand (Office of the National Economic and Social Development Board of Thailand, 2018)

\section{References}

Abidoye, B. O., \& Odusola, A. F. (2015). Climate Change and Economic Growth in Africa: An Econometric Analysis. Journal of African Economies, 24(2), 277-301. doi:10.1093/jae/eju033

Akram, N. (2012). Is climate change hindering economic growth of Asian economies. Asia-Pacific Development Journal, 19(2), 1-18.

Alagidede, P., Adu, G., \& Frimpong, P. B. (2015). The effect of climate change on economic growth: evidence from Sub-Saharan Africa. Environmental Economics and Policy Studies, 18(3), 417-436.

Ali, S. (2012). Climate Change and Economic Growth in a Rain-fed Economy: How Much Does Rainfall Variability Cost Ethiopia?. EEA Working paper Series. Ethiopian Economics Association, Addis Ababa, Ethiopia

Auffhammer, M., Hsiang, S. M., Schlenker, W., \& Sobel, A. (2013). Using weather data and climate model output in economic analyses of climate change. Review of Environmental Economics and Policy, 7(2), 181198.

Barrios, S., Bertinelli, L., \& Strobl, E. (2010). Trends in rainfall and economic growth in Africa: A neglected cause of the African growth tragedy. The Review of Economics and Statistics, 92(2), 350-366.

Barro, R. J. (1990). Government spending in a simple model of endogeneous growth. Journal of political economy, 98(5, Part 2), S103-S125.

Berlemann, M., \& Wenzel, D. (2015). Long-term Growth Effects of Natural Disasters-Empirical Evidence for Droughts. CESifo Working Paper No. 5598. CESifo Center for Economic Studies \& Ifo Institute, Munich, Germany.

Berlemann, M., \& Wenzel, D. (2018). Precipitation and Economic Growth. CESifo Working Paper No. 7258. Munich Society for the Promotion of Economic Research - CESifo GmbH, Munich, Germany.

Borgomeo, E., Vadheim, B., Woldeyes, F. B., Alamirew, T., Tamru, S., Charles, K. J., . . Walker, O. (2018). The Distributional and Multi-Sectoral Impacts of Rainfall Shocks: Evidence From Computable General Equilibrium Modelling for the Awash Basin, Ethiopia. Ecological Economics, 146, 621-632. doi:10.1016/j.ecolecon.2017.11.038

Brown, C., Meeks, R., Ghile, Y., \& Hunu, K. (2013). Is water security necessary? An empirical analysis of the effects of climate hazards on national-level economic growth. Phil. Trans. R. Soc. A, 371(2002), 20120416.

Bruton, M. N. (1979). The breeding biology and early development of Clarias gariepinus (Pisces: Clariidae) in Lake Sibaya, South Africa, with a review of breeding in species of the subgenus Clarias (Clarias). The Transactions of the Zoological Society of London, 35(1), 1-45.

Cabral, F. J. (2014). Rainfall and Economic Growth and Poverty: Evidence from Senegal and Burkina Faso. African Growth \& Development Policy (AGRODEP) Modeling Consortium.

Cline, W. R. (2007). Global warming and agriculture: Impact estimates by country: Peterson Institute.

Coale, A. J., \& Hoover, E. M. (1958). Population growth and economic development in low-income countries: a case study of India's prospects. 
Dell, M., Jones, B. F., \& Olken, B. A. (2009). Temperature and income: reconciling new cross-sectional and panel estimates. American Economic Review, 99(2), 198-204.

Dell, M., Jones, B. F., \& Olken, B. A. (2012). Temperature shocks and economic growth: Evidence from the last half century. American Economic Journal: Macroeconomics, 4(3), 66-95.

Dell, M., Jones, B. F., \& Olken, B. A. (2014). What Do We Learn from the Weather? The New Climate-Economy Literature $\dagger$. Journal of Economic Literature, 52(3), 740-798. doi:10.1257/jel.52.3.740

Department of Provincial Administration. (2018). Population at the provincial level report. Retrieved from Bangkok,Thailand:http://stat.bora.dopa.go.th/stat/statnew/statTDD/views/showDistrictData.php?rcode=10\& statType $=1$ \&year $=36$

Dkhar, D. K., Feroze, S., Singh, R., \& Ray, L. I. (2017). Effect of rainfall variability on rice yield in north eastern hills of India: a case study. Agricultural Research, 6(4), 341-346.

Feng, S., Krueger, A. B., \& Oppenheimer, M. (2010). Linkages among climate change, crop yields and MexicoUS cross-border migration. Proceedings of the National Academy of Sciences, 107(32), 14257-14262.

Gadgil, S., \& Gadgil, S. (2006). The Indian Monsoon, GDP and Agriculture. Economic and Political Weekly, 41(47), 4887-4895.

Guiteras, R. (2009). The impact of climate change on Indian agriculture. Manuscript, Department of Economics, University of Maryland, College Park, Maryland.

Horowitz, J. K. (2009). The income-temperature relationship in a cross-section of countries and its implications for predicting the effects of global warming. Environmental and resource economics, 44(4), 475-493.

Intralawan, A., Wood, D., Frankel, R., Costanza, R., \& Kubiszewski, I. (2018). Tradeoff analysis between electricity generation and ecosystem services in the Lower Mekong Basin. Ecosystem Services, 30, 27-35. doi:10.1016/j.ecoser.2018.01.007

IPCC, C. C. (2007). The physical science basis. Contribution of working group I to the fourth assessment report of the intergovernmental panel on climate change. Manning, M., Chen, Z., Marquis, M., Averyt, KB, Tignor, M., and Miller, HL, Cambridge University Press, Cambridge, UK and New York, NY, USA, 996, 2007.

Isik, M., \& Devadoss, S. (2006). An analysis of the impact of climate change on crop yields and yield variability. Applied Economics, 38(7), 835-844. doi:10.1080/00036840500193682

James, H. S., \& Mark, W. W. (2011). Introduction to Econometrics. Boston, MA: Pearson Education.

Karnatak, G., Sarkar, U. K., Naskar, M., Roy, K., Gupta, S., Nandy, S. K., . . Bose, A. K. (2018). Understanding the role of climatic and environmental variables in gonadal maturation and spawning periodicity of spotted snakehead, Channa punctata (Bloch, 1793) in a tropical floodplain wetland, India. Environmental Biology of Fishes, 101(4), 595-607.

Lanzafame, M. (2014). Temperature, rainfall and economic growth in Africa. Empirical Economics, 46(1), 1-18.

Lertamphainont, S., \& Sparrow, R. (2016). The Economic Impacts of Extreme Rainfall Events on Farming Households: Evidence from Thailand. PIER Discussion Papers No.45. Puey Ungphakorn Institute for Economic Research, Bangkok, Thailand.

Levine, D. I., \& Yang, D. (2014). The impact of rainfall on rice output in Indonesia. Retrieved from

Loayza, N. V., Olaberria, E., Rigolini, J., \& Christiaensen, L. (2012). Natural disasters and growth: Going beyond the averages. World Development, 40(7), 1317-1336.

Mankiw, N. G., Romer, D., \& Weil, D. N. (1992). A contribution to the empirics of economic growth. The quarterly journal of economics, 107(2), 407-437.

Mendelsohn, R. (2008). The impact of climate change on agriculture in developing countries. Journal of Natural Resources Policy Research, 1(1), 5-19.

Miguel, E., \& Satyanath, S. (2011). Re-examining economic shocks and civil conflict. American Economic Journal: Applied Economics, 3(4), 228-232.

MOC, T. M. o. C. o. t. K. o. T. (2015). Top 10 export agricultural products of Thailand. http://www2.ops3.moc.go.th/

Murad, W., Islam Molla, R., Bin Mokhtar, M., \& Raquib, A. (2010). Climate change and agricultural growth: an examination of the link in Malaysia. International Journal of Climate Change Strategies and Management, 2(4), 403-417.

Nordhaus, W. D. (1991). To slow or not to slow: the economics of the greenhouse effect. The economic journal, 101(407), 920-937.

Odusola, A., \& Abidoye, B. (2015). Effects of Temperature and Rainfall Shocks on Economic Growth in Africa. Paper presented at the International Association of Agricultural Economists 29th Triennial conference.

Office of the National Economic and Social Development Board of Thailand. (2017). Gross Regional and Provincial Product Chain Volume Measures 2017 Edition. Retrieved from The Office of the Prime Misnister, Bangkok, Thailand:

Office of the National Economic and Social Development Board of Thailand. (2018). Gross Provincial Product. https://www.nesdb.go.th/main.php?filename=gross_regional. 
Pawaputanon Na Mahasarakarm, O. (2007). An Introduction to the Mekong Fisheries of Thailand. Mekong Development Series No. 5. Mekong River Commission, Vientiane, Lao PDR. 54 Pages.

Phatcharopaswatanagul, A. (2018). Impacts of climate change on casava in Northeastern of Thailand, Ph.D. thesis. Maejo University, Chiang Mai, Thailand.

Phomikong, P., Udduang, S., Fukushima, M., Srichareondham, B., Rattanachamnong, D., \& Jutagate, T. (2018). Larval fish assemblage patterns in three tributaries of Mekong River in Thailand. INDIAN JOURNAL OF FISHERIES, 65(2), 1-15.

Richardson, C. J. (2007). How much did droughts matter? Linking rainfall and GDP growth in Zimbabwe. African Affairs, 106(424), 463-478.

Schlenker, W., \& Lobell, D. B. (2010). Robust negative impacts of climate change on African agriculture. Environmental Research Letters, 5(1), 014010.

Schlenker, W., \& Roberts, M. J. (2009). Nonlinear temperature effects indicate severe damages to US crop yields under climate change. Proceedings of the National Academy of Sciences, 106(37), 15594-15598.

Sebastien, H. (2010). Econometric study on the impact of rainfall variability on security in the Sahel region. Retrieved from The Organisation for Economic Co-operation and Development (OECD) website: https://www.oecd.org/swac/publications/44245104.pdf.

Sequeira, T. N., Santos, M. S., \& Magalhães, M. (2018). Climate change and economic growth: a heterogeneous panel data approach. Environmental Science and Pollution Research, 1-11.

Sharma, A., Naskar, M., Joshi, K., Bhattacharjya, B., Sahu, S., Das, S., . . Das, M. (2014). Impact of climate variation on breeding of major fish species in inland waters (CIFRI Bulletin no. 185): Central Inland Fisheries Research Institute.

Sinnarong, N., Pongcharoen, K., Thaeye, K., Phuntulee, S., \& Ngampiboonwet, W. (2018). The association of weather variables with rice production and simulation of agro-adaptation measure for northeast Thailand: evidence from panel data model. International Journal of Global Warming, 14(3), 330-355.

Solow, R. M. (1956). A contribution to the theory of economic growth. The quarterly journal of economics, $70(1), 65-94$.

Stacey, N. (1984). Control of the timing of ovulation by exogenous and endogenous factors. Fish reproduction: Strategies and tactics, 207-222.

Tebaldi, E., \& Beaudin, L. (2016). Climate change and economic growth in Brazil. Applied Economics Letters, 23(5), 377-381.

Thai Meteorological Department. (2018). Annual weather report. Retrieved from Bangkok, Thailand:

The National Statistic Office of Thailand. (2018). The Labour Force Survey Whole Kingdom. The National Statistic Office of Thailand, Bangkok, Thailand.

United Nations Statistics Division. (1986). Standard International Trade Classification Revision 3, Series M: Miscellaneous Statistical Papers, No. 34 Rev. 3, New York: United Nations. ST/ESA/STAT/SER.M/34/Rev.3. https://unstats.un.org/unsd/publication/seriesm/seriesm_4rev3_1e.pdf.

Welcomme, R. (2008). Inland fisheries: ecology and management: John Wiley \& Sons.

Wooldridge, J. M. (2015). Introductory econometrics: A modern approach: Nelson Education.

Woynarovich, E., \& Horváth, L. (1980). The artificial propagation of warm-water finfishes: a manual for extension.

Zeb, A. (2013). Climate Change and Economic Growth in Nordic Countries: An application of smooth coefficient semi-parametric approach. International Journal of Social Sciences, II(3), 159-171. 